\title{
Forma de la novela, ideologema e identidad en Alejo Carpentier y Miguel Ángel Asturias
}

José García-Romeu ${ }^{1}$

Resumen. Este trabajo estudia dos novelas representativas del realismo maravilloso, Los pasos perdidos de Alejo Carpentier y Mulata de tal de Miguel Ángel Asturias, a fin de destacar cómo cada escritor encara la relación entre las estructuras novelísticas y las representaciones ideológicas de la identidad hispanoamericana con la reactivación de elementos estéticos sacados de diferentes ámbitos de la cultura popular.

Palabras clave: Asturias (Miguel Ángel); Carpentier (Alejo); cultura popular; ideologema; realismo maravilloso.

[en] Novel form, ideologeme and indentity in the work of Alejo Carpentier and Miguel Ángel Asturias

\begin{abstract}
This article looks at two novels typical of magical realism, Alejo Carpentier's The Lost Steps and Miguel Ángel Asturias's Mulata de tal, to analyse how each of these writers deals with novelistic structure and the ideological representations of Latin American identity by reactivating aesthetic elements borrowed from various fields of popular culture.
\end{abstract}

Keywords: Asturias (Miguel Ángel); Carpentier (Alejo); popular culture; ideologeme; magical realism.

Sumario: 1. Alejo Carpentier: Los pasos perdidos, 1953. 1.1. Cronotopo 1: orden regresivo. 1.2. Estructura 1: relato arcaico. 1.2.1. El héroe, el falso héroe y la princesa. 1.2.2. El mandador. 1.2.3. Los donantes y los auxiliares mágicos. 1.2.4. Los agresores. 1.3. Conclusión I. 2. Miguel Ángel Asturias: Mulata de tal, 1963. 2.1. Cronotopo 2: desorden transgresivo. 2.2. Estructura 2: relato plebeyo. 2.2.1. El golpe sorpresivo. 2.2.2. El suspenso. 2.2.3. El repaso. 2.2.4. La ramificación. 2.3. Conclusión II.

Cómo citar: García-Romeu, J. (2021) Forma de la novela, ideologema e identidad en Alejo Carpentier y Miguel Ángel Asturias, en Anales de Literatua Hispanoamericana 50, 189-200.

Aclimatando al medio americano la teoría de Tzvetan Todorov acerca de las distinciones entre lo maravilloso y lo fantástico, Ana María Barrenechea advierte en 1979 que ambas nociones son definidas por la realidad extratextual (en relación con lo que la sociedad considera normal o anormal en una época dada) y el sistema intratextual (en relación con formas literarias que perduran más allá de la cultura históricamente determinada que las produjo). A partir de ahí observa cómo lo real maravilloso y el realismo mágico alteran los códigos al describir hechos ficticios que no se ajustan precisamente con la visión de ninguna cultura identificable: ni la animista, ni la católica, ni la científica... sino que lo mezclan todo. De ello se infiere que dichas estéticas combinan los paradigmas culturales sucesivos en que nacieron lo fantástico y lo maravilloso. Éste no sería por lo tanto -al contrario de lo que pretende Roger Caillois (1958)- un principio obsoleto que aquél habría postergado.

Sabemos que los fundadores de lo real maravilloso y del realismo mágico (Uslar Pietri, Carpentier, Asturias) no podían coincidir con la interpretación cronológica de Caillois ya que habían intentado superar las categorías acuñadas por la sucesión histórica hegeliana con el fin de reactivar, contra la idea de progreso continuo y de evolucionismo, los mitos autóctonos que revelaran una humanidad americana, auténtica y perenne. Al recuperar lo propio, se rompía el cerco del racionalismo europeo y se creaban universos

\footnotetext{
${ }^{1}$ Université de Toulon. Francia.

E-mail: jose.garcia-romeu@univ-tln.fr
} 
ficcionales a medio camino entre lo realista, lo fantástico y lo maravilloso, con fuerte impregnación de creencias tradicionales. También influyeron en la valoración estética de esas creencias tanto los estudios antropológicos y etnológicos ${ }^{2}$, despejados de su más visible etnocentrismo occidental, como la reivindicación de culturas populares marginadas por las elites blancas. El fenómeno, específico a América Latina, sintoniza además con un movimiento literario más universal gracias al cual el texto asume un trabajo de desrealización y deja de funcionar como el reflejo de la supuesta realidad extratextual para adentrarse cada vez más en lo autorreferencial. Desde entonces, las generalizaciones según las cuales "la realidad latinoamericana [icuán maravillosa!] supera la ficción" pasan a representar una perspectiva de análisis inadecuada -inoperante en gran parte de la literatura de los siglos XX y XXI- obnubilada por la limitada preocupación de escapar al mimetismo realista stendhaliano mediante otro mimetismo. Expresiones como ésta de Patrick Collard, por ejemplo, sólo han participado en establecer una difusa naturalización folclorista de América:

Lo maravilloso [...] es asombroso, por lo insólito. Todo lo insólito, todo lo asombroso, todo lo que sale de las normas establecidas es maravilloso y lo real-maravilloso es lo que encontramos en estado bruto, latente, omnipresente en todo lo latinoamericano. (Collard, 1991: 110)

En realidad, Collard parafrasea una famosa conferencia de Alejo Carpentier (Carpentier, 1981: 111-135) ${ }^{3}$, que a su vez parafrasea en parte su "Prólogo" del Reino de este mundo. ${ }^{4}$ En ambos textos, por ser americano, Alejo Carpentier encubre el hecho de que su visión real-maravillosa no funciona sino desde un punto de vista occidental al fundar como exóticas y esencializadas las cosmogonías de las poblaciones afrocaribeñas de los siglos XVIII y XIX.

En las páginas siguientes, en que intentamos registrar la relación entre forma novelística e ideología en Alejo Carpentier y en Miguel Ángel Asturias, ignoraremos dos graves cuestiones que dieron mucho que debatir: (1) la de la relación entre una presunta realidad americana y sus representaciones supuestamente maravillosas que acabamos de evocar; (2) la de las distinciones entre lo real maravilloso y el realismo mágico cuyo planteamiento previo parece necesario en cuanto se comparan las obras del escritor cubano con las del guatemalteco. Como adolecemos de borgesianismo y de goodmanismo ${ }^{5}$, descartamos sin mayor escrúpulo la primera cuestión. Quien quiera examinar la segunda puede leer el acertado análisis de Alicia Llarena (1997b), que opone la narración neutra de Alejo Carpentier (cuya objetividad produce un efecto de contraste entre lo racional y lo maravilloso) a la sincrética de Miguel Ángel Asturias (que precipita al contrario un amalgama entre los dos polos). Nosotros, según el ejemplo de Irlemar Chiampi, abarcaremos ambas estéticas bajo el término coagulante de "realismo maravilloso". 6

Propuesta esa unificación y abandonadas las preocupaciones acerca de lo maravilloso como representación de la realidad, podemos ahora verificar cómo se distinguen -en sus textos y sin preocuparnos a priori por interpretaciones teóricas generales- las estéticas de Carpentier y de Asturias, señalados escritores del realismo maravilloso. No se trata de hacer un compendio de las diferencias sino de examinar sus respectivos ideologemas ${ }^{7}$ en relación con una de las problemáticas cardinales de sendos proyectos literarios: la identidad americana y la forma novelística más adecuada para manifestarla.

Pensamos que tratar este asunto a partir de dos textos canónicos es la manera más apropiada de resolverlo con éxito, sobre todo que dichos textos contemplan un elemento original de la americanidad: la Conquista y sus consecuencias. Nos detendremos pues, en primer lugar, en Alejo Carpentier y en Los pasos perdidos que exhuma la posibilidad de un encuentro lascasiano entre culturas. Veremos luego cómo Miguel Ángel Asturias reinterpreta en Mulata de tal el choque del encuentro de manera más audaz y pesimista.

\footnotetext{
${ }^{2}$ Para comprobarlo, basta citar el descubrimiento del Popol Vuh por Asturias en París, durante las clases del profesor Georges Raynaud.

3 "Lo barroco y lo real maravilloso", conferencia pronunciada en 1975. Ver en particular la p. 127.

${ }^{4}$ Carpentier concluye el "Prólogo” con esta contundente naturalización: “¿Pero qué es la historia de América toda sino una crónica de lo real maravilloso?" (Carpentier, 1967: 16).

${ }^{5}$ Goodman considera que sólo existen versiones de mundos y no un mundo real propiamente dicho. Su lectura relativista anula la noción misma de realidad como patrón fijo y absoluto a partir del cual se podría medir lo irreal. En cuanto a Borges, ya sabemos que no admite ninguna existencia fuera de la letra misma. En ese territorio difuso y simbólico del verbo, tampoco tiene sentido interrogarse acerca de lo que es o no la "realidad".

${ }^{6}$ Ver Chiampi, "Realismo maravilloso y literatura fantásticas", Eco, núm. 229, 1980, p. 79-101, citado por Llarena 1997b: 109. Se puede leer un interesantísimo repaso histórico de la crítica dedicada a deslindar ambas corrientes en Llarena 1997a: 21-66.

${ }^{7}$ Por ideologema, nosotros designamos una unidad convencional (un personaje arquetípico, un recurso formal determinado...) que plasma -por su carácter histórico y sus contextos de aparición y de reminiscencia- ciertos sentidos ideológicos. El ideologema transmite esos sentidos al texto que lo integra, pero el texto modifica a su vez el ideologema al insertarlo en su propia trama e hibridándolo con otros ideologemas. Para una definición “más oficial” de la noción inventada por Medvedev (1928), ver Kristeva (que cita a Medvedev) 1968: 103-104 y 1969: $52-53$.
} 


\section{Alejo Carpentier: Los pasos perdidos, 1953}

En Lectura de Los pasos perdidos de Alejo Carpentier, Javier García Méndez comprobó cómo la novela del escritor cubano resistía a las heteroglosias sociales que asaltaban la novela latinoamericana de su tiempo mediante el uso de una lengua hierática y de una enciclopedia cultísima. Nuestro propósito es vislumbrar la manera en que esa reacción antimoderna se revela también en la descripción de un cronotopo particular, que promueve una Arcadia primigenia ${ }^{8}$, un mundo ideal que renueva en términos positivos el encuentro colonizador por medio de una regresión maravillosa. Esa regresión es transmitida lógicamente por una estructura literaria retrógrada, próxima a la del cuento tradicional. Todo ello expone una ideología que Georg Lukács hubiera calificado de épica y que se expresa, no sin contradicciones, dentro de la forma novelística contemporánea.

\subsection{Cronotopo 1: orden regresivo}

La novela de Alejo Carpentier cuenta día a día, según los recursos de la crónica de viaje, el recorrido del narrador por el espacio americano desde una moderna ciudad de los Estados Unidos hasta un poblado de la selva sudamericana cuyo modo de fundación recuerda los tiempos de la Conquista. Escribe Juan Durán Luzio:

Elaborada sobre el esquema tradicional de un viaje hacia lo desconocido por un protagonista que tiene misión que cumplir y deber de regresar [...], el proceso de búsqueda completo diseña la ruta hacia una Arcadia. En este caso, una Arcadia en el Nuevo Mundo. (Durán Luzio, 1978: 158-159)

El recorrido espacial del narrador puede leerse también como un viaje al origen en un mundo bipolar ${ }^{9}$ en que, separados por las etapas de un proceso iniciático, las raíces más remotas sobreviven simultáneamente a los adelantos más modernos ${ }^{10}$ :

Conocía a los ciegos y baldados de sus calles; los emplastos, solimanes y Sálsamos curanderos con que aliviaban sus dolores. Pero los conocía a través del barniz de las pinacotecas, como testimonio de un pasado muerto, sin recuperación posible. Y he aquí que ese pasado, de súbito, se hace presente. Que lo palpo y aspiro. Que vislumbro ahora la estupefaciente posibilidad de viajar en el tiempo [...]. (Carpentier 2003: 181182)

Al hacer del viaje físico un viaje en el pasado, el relato cumple, pese a su exigente erudición, con los patrones de la narrativa popular dedicada a los mundos perdidos. ${ }^{11}$ Mariano Martín Rodríguez escribe:

La mutación de mentalidades propiciada por la Revolución Industrial favoreció, entre otras cosas, un enriquecimiento de la literatura centrada en pintar sociedades radicalmente distintas a las del mundo real [...]. Por ejemplo, la creciente influencia del progreso científico y técnico facilitó una boga también creciente de la ciencia ficción [...]. Otro género de enorme fortuna popular [...] situaba la ciudad imaginaria no en un futuro fantaseado, sino en el pasado, un pasado milagrosamente pervivido para disfrute del aventurero y, subsidiariamente, de los lectores. De esta forma, se perseguía a la vez el atractivo de la ambientación histórica y el de la explotación literaria del deseo utópico. Este género es lo que se suele denominar en inglés lost-race fiction o lost world romance y que en español podríamos llamar arqueoficción [...]. (Martín Rodríguez: s.p. $)^{12}$

Los pasos perdidos, en cuanto arqueoficción, ha de transportar al protagonista a un cronotopo natural, preservado de la modernidad, cuya pureza se revela desde un principio en el cuerpo mismo de los habitantes:

\footnotetext{
${ }^{8}$ Por lo cual nos vamos a interesar sobre todo por los capítulos IV y V en los que aparece esa Arcadia.

${ }^{9}$ La novela opone pues dos universos. Nosotros examinaremos el más primitivo, auténtico y vital. El lector interesado por el más moderno, artificial y morboso, podrá leer el trabajo de Juan-Navarro.

${ }^{10}$ Aplicando las observaciones que había hecho en el "Prólogo" del Reino de este mundo, Alejo Carpentier pone así de relieve la vigencia, en América, de creencias que brindan al escritor un aparato cultural más eficiente para la ostentación de lo maravilloso que las invenciones artificiales y escépticas de la literatura europea.

${ }^{11}$ King Solomon's Mines (1885) de Henry Rider Haggard, The lost World (1912) de Arthur Conan Doyle y The land that time forgot (1918) de Edgar Rice Burroughs son las incidencias más conocidas de esa narrativa.

12 Subraya el autor.
} 
En torno mío cada cual estaba entregado a las ocupaciones que le fueran propias, en un apacible concierto de tareas que eran las de una vida sometida a los ritmos primordiales. Aquellos indios [...] me resultaban, en su ámbito, en su medio, absolutamente dueños de su cultura. Nada era más ajeno a su realidad que el absurdo concepto del salvaje. (Carpentier, 2003: 176)

Había perfiles de una singular nobleza, por lo aguileño de las narices y la espesura de las cabelleras. Por lo demás, el desarrollo de los cuerpos estaba cumplido en función de utilidad [...]. Cada cual llevaba su esqueleto dentro, envuelto en carnes eficientes. Por lo menos, aquí no había oficios inútiles, como los que yo hubiera desempeñado durante tantos años. (Carpentier, 2003: 177)

Martín Rodríguez ve en algunas arqueoficciones la expresión del colonialismo occidental. Los pasos perdidos coincide también en este aspecto con las convenciones del género, aunque su colonialismo sea el del ideal misionero y no el del imperialismo decimonónico que sustenta a menudo ese tipo de literatura. En efecto, si la etnografía estructuralista parece haber dejado en Alejo Carpentier su huella a través de la valoración del primitivo - dueño de "su cultura" y capaz de dominar las circunstancias que lo rodean-, Los pasos perdidos insiste sobre todo en un utópico mundo lascasiano: como ideologemas actanciales, el personaje del Adelantado (heroico civilizador) y el de fray Pedro (buen evangelizador) ${ }^{13}$ patrocinan una conquista paternalista, purificada de la obsesión aurífera que empañó la realidad histórica. Tal como se manifiesta en el poblado de Santa Mónica de los Venados, la invención de Carpentier es pues una suave Arcadia colonial, preservada del prometeísmo moderno que encarnara Tubalcaín, el primer herrero bíblico:

[...] el Adelantado ha fundado una ciudad [...]. Se puede ser Fundador de una Ciudad. Crear y gobernar una ciudad que no figura en los mapas, que se sustraiga a los horrores de la Época, que nazca así, de la voluntad de un hombre, en este mundo del Génesis. La primera ciudad. La ciudad de Henoch, edificada cuando aún no [había...] nacido Tubalcain, el herrero [...]. (Carpentier, 2003: 192)

Sin embargo, por recoger ciertas nociones naturalizadas desde el siglo XIX por el cientificismo antropológico, ese mundo puro y primigenio no está a salvo de un racismo evolucionista. Ya podíamos sospechar semejante tendencia en el narrador cuando describía la eficiencia física de los indios y la "singular nobleza" de su nariz aguileña. ${ }^{14}$ Las Casas reinterpretado por una suerte de darwinismo social, he ahí un elemento de Los pasos perdidos tal vez poco comentado pero que se manifiesta con fuerza en este pasaje:

El Adelantado [...] me hace asomarme a un hueco fangoso, suerte de zahúrda hedionda, llena de huesos roídos, donde veo erguirse las más horribles cosas que mis ojos hayan conocido: son como dos fetos vivientes, con barbas blancas, en cuyas bocas belfudas gimotea algo semejante al vagido de un recién nacido; enanos arrugados, de vientres enormes, cubiertos de venas azules como figuras de planchas anatómicas, que sonríen estúpidamente, con algo temeroso y servil en la mirada, metiéndose los dedos entre los colmillos [...]. Siento una suerte de vértigo ante la posibilidad de otros escalafones de retroceso, al pensar que esas larvas humanas, de cuyas ingles cuelga un sexo eréctil como el mío, no sean todavía lo último. Que puedan existir, en parte, cautivos de esos cautivos, erigidos a su vez en especie superior, predilecta y autorizada [...]. (Carpentier, 2003: 185-186) ${ }^{15}$

La noción de sucesión temporal no se verifica sólo con el regreso al origen de la Conquista, sino también con la idea de que existen razas más o menos evolucionadas, avalando la imagen de una pirámide en cuya cumbre se encuentra el hombre actual -el narrador-, manifestando la evidencia de un diseño superior. Esta sucesión ya no es histórica, sino biológica. Se deja la historia humana para entrar en la historia natural, como lo muestra el hueco lleno de huesos roídos que remeda una excavación paleontológica. En esa escala, propicia para el desarrollo de la arqueoficción, la jerarquía de las razas adquiere un sentido cabal. Y de nada sirve señalar el anatómico parentesco sexual ni el probable sentido crítico de los términos "especie superior, predilecta y autorizada": de todos modos el narrador comprueba la evidencia de la jerarquía racial por el

\footnotetext{
${ }^{13}$ A propósito de Fray Pedro, escribe Juan Durán Luzio: “diríase un fraile hecho en el cristianismo primitivo predicado y vivido por algunos misioneros tempranos del Nuevo Mundo como Bartolomé de Las Casas" (Durán Luzio, 1978: 164).

${ }^{14}$ Según los criterios de la antropometría decimonónica, ¿no es, la nariz aguileña, atributo de las razas superiores, por oposición a negros y amarillos, ñatos?

${ }^{15}$ Subraya el autor.
} 
horror que le inspiran esos seres inferiores cuya invención literaria apuntala en "el-mundo-real-en-lanovela" ${ }^{16}$ teorías turbias fuera de él.

Esa amplia temporalidad natural no se mide sólo en el trecho biológico que separa las razas sino también en el geológico que organiza el paisaje. Y para la coherencia del proyecto, es necesario que las manifestaciones minerales confirmen, como las humanas, que el viaje del narrador es un viaje al origen. En aquel universo primigenio, la naturaleza es descomunal; vence la erosión y el tiempo; brinda un modelo mágico para las creaciones humanas posteriores:

[...] se alzaban unas moles de roca negra, enormes, macizas, de flancos verticales, como tiradas a plomada, que eran presencia y verdad de monumentos fabulosos. Tenía mi memoria que irse al mundo del Bosco, a las Babeles imaginarias de los pintores de lo fantástico, de los más alucinados ilustradores de tentaciones de santos, para hallar algo semejante a lo que estaba contemplando. Y aun cuando encontraba una analogía, tenía que renunciar a ella, al punto, por una cuestión de proporciones. Esto que miraba era algo como una titánica ciudad [...] con escaleras ciclópeas, mausoleos metidos en las nubes, explanadas inmensas dominadas por extrañas fortalezas de obsidiana, sin almenas ni troneras, que parecían estar ahí para defender la entrada de algún reino prohibido al hombre. Y allá, sobre aquel fondo de cirros, se afirmaba la Capital de las Formas: una increíble catedral gótica, de una milla de alto, con sus torres, su nave, su ábside y sus arbotantes, montada sobre un peñón cónico hecho de una materia extraña [...]. En las proporciones de esas Formas rematadas por vertiginosas terrazas, flanqueadas con tuberías de órgano, había algo tan fuera de lo real -morada de dioses, tronos y graderíos destinados a la celebración de algún Juicio Final- que el ánimo, pasmado, no buscaba la menor interpretación de aquella desconcertante arquitectura telúrica, aceptando sin razonar su belleza vertical e inexorable. (Carpentier, 2003: 175) ${ }^{17}$

“[...] el ánimo, pasmado, no buscaba la menor interpretación”, escribe el narrador quien propone sin embargo -gracias a la retrospección que la escritura permite- una interpretación: la de un escenario maravilloso, constituido por los dioses, tribunal edificado en espera de "algún Juicio Final". Este paisaje monumental cumple con dos funciones: (1) es una creación incorrupta que expone la Idea original que los hombres habrán de imitar (la catedral identificada por el narrador es la catedral perfecta y no un conjunto que se le parezca casualmente); (2) es un tribunal divino que anuncia la condena final. Tiene por lo tanto una dimensión genética y escatológica: inscrito en un tiempo circular, es origen y fin.

Ya Michel Butor había observado que Jules Verne otorgaba a los paisajes naturales aquel carácter de Idea por proyectar, que los hombres reproducirían con el adelanto tecnológico:

[En Jules Verne] el hombre se encuentra en profunda connivencia con las cosas, que bosquejan las invenciones humanas. [...] la propia naturaleza sueña y [...] el hombre termina ejecutando esos mismos sueños, en una escala menor tal vez, con menor magnitud, pero sin embargo con mayor perfección: los termina, les da su verdadero fin. Cumple con las promesas inscritas en las cosas.

Relevante en efecto es la abundancia [en las descripciones de Jules Verne] de esos arcos, esos pilares, esas bóvedas, esos castillos aparentes, esas catedrales naturales [...]. (Butor, 1960: 41-43) $)^{18}$

Sorprendentemente, Verne y Carpentier coinciden en diseñar la naturaleza original como patrón de las invenciones humanas. Pero aquí se acaba la semejanza. Para Verne la naturaleza es una materia física. Puede ser utilizada y sus modelos mejorados. Para Carpentier es un principio sagrado. Tiene que ser admirada y sus modelos imitados. El instrumento que el francés considera adecuado para interpretar ese mundo es la ciencia, y la novela adquiere pues un carácter didáctico: remonta las edades antediluvianas para leer en ellas el pronóstico teleológico del progreso humano. El instrumento que utiliza el cubano para averiguar el sentido del universo es la mística, y la novela se proyecta en el futuro para revelar una profecía escatológica. El universo cerrado dominado por la "Capital de las Formas" proclama una ley inmutable, inmejorable, prescripta por misteriosos dioses, según la cual los hombres serán juzgados. Al contrario de la concepción de Verne, ello supone la desconfianza hacia el actuar humano, profanatorio, y la impugnación de ese actuar por reglas superiores y sobrenaturales. La idea de un evolucionismo racial que observáramos poco antes viene a

\footnotetext{
${ }^{16}$ La expresión, que no necesita dilucidación particular, es de Pavel (Pavel, 1988: 81).

${ }^{17}$ Se pueden observar los puntos comunes entre esta descripción ficcional y una real, hecha en ocasión a un viaje en avión por la región del Orinoco y publicada en la revista Carteles en 1948 (Carpentier, 1981: 59-78).

18 Traducimos nosotros.
} 
chocar aquí con la de la eternidad geológica y divina. Mas, la contradicción es solo aparente ya que produce un pertinente efecto de contraste entre la naturaleza y la humanidad. A ésta no le queda otra posibilidad que intentar imitar aquélla, con sus pobres medios, para escapar a la vanidad de la existencia mundana y conseguir, tal vez, la Gracia Final.

\subsection{Estructura 1: relato arcaico}

Si la iniciación vivida por el narrador lo hace retroceder a una especie de edad de oro colonial y ante un universo antediluviano, es probable que la propia estructura de la novela recoja formas arcaicas. Y en efecto, Los pasos perdidos recicla meticulosamente ideologemas propios del cuento tradicional tal como Vladimir Propp los estableció a través de las funciones actanciales. Recordemos que el formalista ruso define dichas funciones como las acciones arquetípicas que configuran a los personajes. Cada cuento está formado por la asociación y la concatenación de varias de esas funciones. Universales y perennes, permiten comprobar la existencia de siete personajes paradigmáticos (Propp, 1970: 96-97):

(1) El héroe/la heroína: supera una serie de pruebas con el fin de resolver una carencia inicial, carencia que puede ser expresada por un mandador o provocada por un agresor.

(2) El agresor: rompe el equilibrio vivencial del protagonista, obligándolo a iniciar una búsqueda que intentará luego estorbar.

(3) El mandador: solicita al héroe para que cumpla con la búsqueda.

(4) El donante: brinda al héroe la posibilidad de superar una o varias pruebas.

(5) El auxiliar mágico, animal u objeto: es otorgado a menudo por el donante.

(6) El falso héroe: compite con el protagonista para conseguir los beneficios de la búsqueda. Falto de perseverancia, hace trampa y fracasa.

(7) La princesa/el príncipe: representa la recompensa final del héroe o de la heroína cuya misión, cumplida, permite un ascenso social por medio del matrimonio.

Si esas funciones suelen aparecer, algo alteradas, en la novela moderna, Carpentier las usa de manera tan sistemática en Los pasos perdidos que regenera casi por completo la estructura rígida del relato tradicional. Renunciando tanto a la ilusión psicológica como a la complejidad antropológica que caracteriza la literatura contemporánea, vuelve a determinar la estructura misma del relato a partir de las funciones actanciales primitivas. Incluso las divergencias que en alguna ocasión distinguen la novela de Carpentier del cuento folclórico adquieren un significado particular, ya que manifiestan justamente una dialéctica reveladora entre éste y aquélla. Para comprobarlo pasaremos revista a los diferentes paradigmas actanciales de Propp, atribuyéndoles la figura que les corresponde en la novela de Carpentier.

\subsubsection{El héroe, el falso héroe y la princesa}

En un principio, el narrador en primera persona es el héroe. Padece una carencia espiritual en una sociedad moderna e inauténtica. Es también misionado por su amigo el Curador para encontrar un instrumento primitivo. Carencia por resolver y misión por cumplir: así se define doblemente el desencadenante que justifica la aventura. Pero la complejidad de la novela contemporánea confunde la obviedad de los paradigmas tradicionales: la búsqueda del instrumento primitivo metaforiza en realidad una búsqueda espiritual más difusa: recuperación de las raíces, del recuerdo de infancia, de la autenticidad primitiva... ${ }^{19} \mathrm{El}$ motivo se desmultiplica pero sigue teniendo un valor uniforme: se trata de regresar a un pasado perfecto. Mas, cuando el narrador alcanza la meta, ocurre un golpe sorpresivo que altera el arquetipo. Transformándose en falso héroe, el protagonista compromete el éxito de su misión; sustituye su actitud desinteresada por la ambición mundana y se deja tentar por Ruth, la esposa moderna y engañosa que lo separa de Rosario, la mujer natural. Mediante una inversión inesperada de las funciones, la novela desbarata los claros y estables atributos del cuento tradicional. Pero esta diferencia se limita a un recurso narrativo y no cambia en el fondo las analogías ideológicas entre el relato popular y la obra del autor cubano. Además, en el momento en que se revela la falsedad del protagonista aparece por contraste la figura de un héroe auténtico:

${ }^{19}$ El tema de la busca como iniciación y recorrido entre dos polos opuestos es el tema más ostensible de la novela. También uno de los más estudiados. Ver por ejemplo Oscar Velayos Zurdo (Velayos Zurdo, 1990: 130 passim). 
Marcos, habitante compatible y legítimo del mundo mítico. Naturalmente, es él quien recupera la recompensa perdida por el narrador: Rosario, versión real-maravillosa de la princesa tradicional.

\subsubsection{El mandador}

Esta función está desempeñada por el Curador, personaje que produce una causalidad mágica al aparecer en un momento muy oportuno y al manifestarse en circunstancias muy simbólicas: presencia de una lluvia purificadora, juego de espejos, estado de desorientación anímica del protagonista que necesita la redentora intervención de un guía...

\subsubsection{Los donantes y los auxiliares mágicos}

A la función anterior, el Curador añade la de donante ya que financia la búsqueda del narrador. Pero en cuanto entiende que el dinero es un maligno atributo materialista, el protagonista planea devolverlo. Finalmente, lo entrega a cierto Herborizador a quien confía también -demostrando el vínculo entre mujer y dinero, trabas en la ascensión hacia la purificación espiritual- a Mouche, su amante. Al tomar esas lacras, el Herborizador cumple con un exorcismo chamánico que libera al narrador de nefastas ataduras. "Tomar" se invierte pues, mágicamente, en "donar". Además del Curador y del Herborizador, existe otro donante: el Adelantado que guía al personaje hasta los orígenes del mundo y de la música.

A menudo, los donantes entregan objetos sobrenaturales al héroe. Propp insiste en particular en los medios de transporte que permiten salvar distancias fenomenales (Propp, 1970: 132). Justamente, ellos no faltan en Los pasos perdidos donde orientan al protagonista en un espacio dividido entre las edades de hierro y de oro. Durante el largo viaje de ida, por ejemplo, el barco sigue los vericuetos del laberinto. Dirigido por el Adelantado, timonel mágico, alcanza el centro del dédalo pasando por un mundo orgánico y acuático, genético y escatológico. Al contrario, durante el viaje de vuelta, el avión que supera en pocas horas la prueba laberíntica de la selva es un auxiliar tramposo. Desenmascara al falso héroe al señalar de manera patente su inconstancia.

\subsubsection{Los agresores}

En Los pasos perdidos, los agresores son los agentes del mundo moderno. Pretenden cerrar el paso del narrador hacia el universo primigenio y provocan sus fracasos: Ruth lo hace caer en la impostura final; Mouche pretende detenerlo durante el viaje de ida y luego, a su regreso, lo denuncia a la prensa como falso héroe; la pintora homosexual canadiense aniquila simbólicamente su virilidad seduciendo a Mouche... No es casual que todos esos personajes sean mujeres, brujas $^{20}$ que se oponen a Rosario, quien se autodenomina "tu mujer", indicando así su sometimiento al varón según claras diferencias genéricas.

\subsection{Conclusión I}

Con suma habilidad, Carpentier aplica a un relato formalmente renovado -caracterizado por la presencia de un narrador ambiguo, por la intertextualidad enciclopédica y por el uso explícito del símbolo ${ }^{21}$ - un aparato tradicional que expresa una visión mítica del mundo. Al recuperar ideologemas arcaicos, el autor rescata un pensamiento épico y maravilloso y propone una alternativa utópica a la Conquista. Pero no puede ignorar los efectos del desencanto contemporáneo: renunciando al llano optimismo del cuento tradicional y centrándose en la figura del falso héroe, a quien otorga la función moderna de narrador homodiegético, no asume hasta sus últimas consecuencias una invención escapista y regresiva. De ahí el fracaso ineludible del narrador y la contradicción interna que conlleva lo real maravilloso como reintegración de una fe primigenia y auténtica mediante una escritura moderna y sofisticada. ${ }^{22}$

\footnotetext{
${ }^{20}$ En ellas, la propensión al disfraz que Collard describe como una teatralidad artificial puede interpretarse también como un juego de metamorfosis diabólicas que embellece falsamente a la horrible bruja (Collard, 1989).

${ }^{21}$ En el cuento tradicional, el símbolo tiene que ser implícito ya que, como lo explicó Bettelheim, no se dirige a la conciencia del receptor (niño) sino a su inconsciente. En una novela culta como Los pasos perdidos, el símbolo puede ser inicialmente implícito, pero su vocación es ser explicitado por un lector (adulto) de quien se espera una interpretación sofisticada capaz de desentrañar conscientemente el sentido de lo simbólico.

${ }^{22}$ Es interesante observar cómo la última novela de Carpentier, El harpa y la sombra, supera la contradicción de Los pasos perdidos al aniquilar toda nostalgia acerca del proyecto colonial.
} 


\section{Miguel Ángel Asturias: Mulata de tal, 1963}

En Mulata de tal, Miguel Ángel Asturias describe una pugna mágica y milenaria entre la cultura indígena y las importadas. Arrancando una gran variedad de ideologemas a su fondo original, atomiza y reorganiza viejos materiales legendarios que incorpora a un nuevo tejido ficcional regido por una amplia hibridación intertextual. De ahí que las referencias constantes pero deformadas al mitológico Popol Vuh y a los cuentos folclóricos de la Guatemala tradicional no permitan del todo apuntalar la fantasía del relato en sistemas culturales determinados. Así es como los gigantes Cabracán y Huracán desempeñan en la novela papeles bastante diferentes de los que cumplen en el Popol Vuh. Igualmente, la negación de la Mulata en dar la cara a su amante durante el acoplamiento puede recordar, según un signo contrario, el relato en el que las doncellas Ixtah e Ixpuch están mandadas por los Señores de las tribus para seducir y "ver la cara" a los dioses Tohil, Avilix y Hacavitz. También el timo del alimento ficticio está reescrito en Mulata de tal donde el episodio de la cabeza de cartón evoca el cuento del falso cangrejo del Popol Vuh. Lo mismo puede decirse de los personajes sacados del folclore criollo: el Sisimite, el Cadejo, la Llorona, la Siguanaba y la Siguamonta dejan de ser cocos desencarnados y se humanizan. ${ }^{23}$

Además de esa conversión de figuras actanciales tradicionales, la novela recupera dos motivos tópicos en cuentos y consejas: el del deseo y el de la ambición, que conducen los personajes a pactar con demonios o a dejarse tentar por hembras maléficas. Los diferentes episodios de Mulata de tal expresan el peligro de tales tentaciones por el poder, la riqueza, el sexo... Ofrecen un catálogo de advertencias muy acordes con las preocupaciones de la mentalidad popular, mentalidad que la novela expresa también en su voz narrativa:

\footnotetext{
¿Qué tipo de voz narrativa abre la novela? Se trata de una voz que va a ubicarse dentro de la conciencia del mundo popular guatemalteco $[\ldots]$.

Este tipo de voz narrativa le permite a Asturias desplazarse ágilmente en el plano de la idiosincrasia popular guatemalteca, dimensión que posibilita revelar juicios de valor, creencias, comportamientos culturales y sensuales, formas de hablar [...]. (Barrientos Tecún, 2000: 873-874)
}

Esa mezcla de caracteres tradicionales con una invención pura -que algunos calificaron de carnavalización ${ }^{24}$ - se complica con el empleo de formas literarias sacadas de las literaturas modernas más populares. En Asturias pues lo popular no proviene sólo de las creencias tradicionales sino también de la literatura por entregas.

\subsection{Cronotopo 2: desorden transgresivo}

El argumento de Mulata de tal puede dividirse en tres tramas principales: (1) las aventuras iniciáticas de la pareja protagonista, Celestino Yumí y Catalina Zabala; (2) la rivalidad amorosa por Celestino entre la Mulata de tal, la Zabala y la Huasanga; (3) el enfrentamiento entre demonios terrígenos y demonios cristianos en la fabulosa ciudad de Tierrapaulita.

La primera trama expone peripecias suscitadas por los motivos de la prueba, del engaño y del aprendizaje, motivos típicos del cuento tradicional cuyos héroes han de superar diferentes obstáculos y entuertos antes de alcanzar un saber que les permita madurar y mejorar su situación social. El motivo del engaño, como hazaña divertida que pone en ridículo a la víctima, es también un elemento central de las consejas populares -que cuentan a menudo las relaciones tramposas entre hombres y diablos. En Mulata de tal el tema aparece en diferentes episodios, como por ejemplo el de Tazol, demonio del maíz que engaña al leñatero Celestino mediante un pacto leonino.

La segunda trama repite el tema del engaño, está vez no en el ámbito de la relación entre demonios y hombres, sino en el de las relaciones de pareja. En este caso tampoco faltan las chanzas populares que relatan tales peripecias. Las relaciones entre pareja permiten explorar y actualizar asimismo los arquetipos genéricos de las mitologías tradicionales y la oposición simbólica entre la luna y el sol (Asturias, 2000b: 1005).

La tercera trama corresponde al elemento más ambicioso y culto de la novela. En términos alucinatorios y maravillosos (Asturias, 2000b: 1006), Asturias transmuta el conflicto entre la cultura indígena y la cultura

\footnotetext{
${ }^{23}$ A propósito de este folclore, ver Lara Figueroa.

${ }^{24}$ Ver Barrientos Tecún (Barrientos Tecún, 2000: 877). Bajtín, inventor del concepto, aplica la carnavalización a la obra de Rabelais, obra que emula la cultura de los carnavales y de las ferias populares.
} 
europea en una guerra entre demonios americanos y demonios cristianos. Éstos desean la multiplicación de los hombres para acumular carne de damnificados mientras aquéllos buscan aniquilar el último génesis, tan errado como los dos anteriores que relatara el Popol Vuh. Se nos dice además que dicha rivalidad remonta al comienzo de esta creación y fue motivada por la posesión del tabaco (Asturias 2000a: 290-305). La conquista de América es por lo tanto un episodio más en una guerra entre principios originales, desdibujada sobre un trasfondo colonial (la explotación del tabaco por demonios extranjeros):

Aquí tocamos, acaso, el verdadero fondo, el leitmotiv de la novela en su más amplia concepción global. A la llegada de los españoles a suelo americano no solamente avanzaron Jehová, Jesús, las divinidades cristianas, católicas, sino con ellos los demonios, Satán y sus legiones, demonios también cristianos o católicos. Las divinidades indígenas fueron sustituidas por las divinidades cristianas, europeas, católicas. Se borraron de los altares los dioses de la lluvia, de las cosechas, de la fecundación, los dadores y protectores de la vida, y se les sustituyó por imágenes de Cristo, de María Madre, de santos y santas. En esta misma forma, y en esos mismos momentos, se sustituían a las fuerzas del mal, fuerzas demoníacas indígenas, por los demonios cristianos o católicos. (Asturias, 2000b: 1008)

Así es como el cronotopo representado por la ciudad de Tierrapaulita alberga una lucha cultural y religiosa que alcanzó en la realidad una dimensión geográfica y cronológica amplísima. Sitio de acceso difícil, comarca apartada que tiene todas las características del mundo al revés imaginado por la fantasía popular, la ciudad es una lupa que exhibe la esencia profunda, en un tiempo corto y en un espacio limitado, de un conflicto secular y continental. La evocación de la Conquista y de sus efectos según ese procedimiento que sacude y trastoca ideologemas anteriores genera parodia y grotesco y derruye las grandes periodizaciones y las claras tipologías de los manuales de historia.

\subsection{Estructura 2: relato plebeyo}

En Mulata de tal, lo popular no sólo aparece en los temas, los personajes, la voz narrativa... Se manifiesta también en la estructura del relato. Mas, mientras los temas derivaban de las chanzas criollas, la forma tiene como fuente la novela por entregas del siglo XIX. Así es como -en la época del "boom" en que se publicaban La muerte de Artemio Cruz, Rayuela, La casa verde..., sesudas novelas para lectores expertosAsturias invierte de manera audaz los términos de la innovación literaria, recuperando con un gesto híbrido ideologemas populares.

Dirigiéndose a nuevos lectores influidos por el periódico moderno y por el aprendizaje entonces reciente de la lectura -alienante o emancipadora, según los casos-, la novela por entregas del siglo XIX (Eugène Sue, Manuel Fernández y González, Eduardo Gutiérrez...) aprovechó recursos formales adecuados a la publicación por episodios y a la recepción popular. Nosotros consideramos esos recursos como ideologemas ya que estructuran la forma novelística para corresponder a un gusto de clase y a prácticas de lectura determinadas por configuraciones sociales particulares. El golpe sorpresivo, el suspenso, el repaso y la ramificación de intrigas participan asimismo en lo que Umberto Eco llamó la estructura sinusoidal, típica del enredo folletinesco, que alterna tensiones y distensiones (Eco, 1978: 68).

\subsubsection{El golpe sorpresivo}

Éste permite revivir el interés de la lectura. Entre muchas otras formas (acontecimiento repentino, respuesta inesperada a un enigma...), se manifiesta en los procesos de revelación sensacional de la identidad de un personaje, procesos cuya importancia Umberto Eco analizó en relación con Le Comte de Monte-Cristo. ${ }^{25}$ Es interesante observar cómo el problema de la anagnórisis se enriquece en Mulata de tal con el principio tradicional de la identidad secreta que protege al individuo contra la brujería. Así deben entenderse los sucesivos cambios de nombre de Celestino en el momento de su encuentro con Jerónimo (capítulo 22). La complejidad del motivo aumenta en este caso cuando Celestino explica que tales cambios pretenden mantener en vida a compañeros muertos de viruela:

Mientras yo viva y me llame como ellos se llamaban en la vida, no habrán muerto. Es una forma de magia lógica. Y no soy yo, mi buen señor sacristán, quien carga sus nombres. Son ellos, sus nombres, sílabas y 
sonidos, los que me cargan a mí y me devuelven a antes del santo kak o santo fuego, a tiempos más felices. (Asturias, 2000a: 246) ${ }^{26}$

Además de provocar un tipo muy común de golpe sorpresivo, constituido por una de las convenciones más antiguas de la novela de aventuras y de la comedia, la anagnórisis se ve transfigurada y aumentada por nociones chamánicas (nombre secreto y papel mediador del antepasado) y por nostalgias memoriales (homenaje a los muertos y recuerdo de tiempos mejores), todo lo cual refleja las técnicas de aglutinación de los ideologemas habilitadas por la escritura asturiana para generar plurivocalidad.

\subsubsection{El suspenso}

Este procedimiento es la causa narrativa del anterior ya que mantiene la duda acerca del resultado de una acción hasta su conclusión repentina mediante el golpe sorpresivo. Provoca la impaciencia del lector y le incita a acelerar la lectura de la novela. En el caso de los folletines, el proceso está reforzado por las interrupciones episódicas e impulsa a los lectores a comprar la entrega siguiente. Jean-Yves Tadié contempló la importancia de la receta y sus efectos sinusoidales en la novela de aventuras:

La novela de aventuras organiza el suspenso de manera que ningún acontecimiento conlleve un sentido inmediato y que su solución (en términos de vida y de muerte) y su explicación (en términos de verdad y de error) siempre sean postergadas. Como no hay tensión sin distensión, el descanso, la felicidad aparentes sólo son relatados y el cómico sólo es usado para ir preparando a lo peor, porque el horror continuo provoca indiferencia; asimismo, la angustia se nutre de intervalos serenos. (Tadié, 1982: 8)

[...] si el suspenso es experimentado por los personajes, es sobre todo un sentimiento que el novelista procura provocar en el lector; ese sentimiento es un placer contagiado de angustia; el deseo de aprender se mezcla con el miedo de saber (Edipo), incluso la fascinación con la repulsión; por fin, última observación, empírica esta vez, la lectura no puede ser interrumpida [...]. (Tadié, 1982: 62) ${ }^{27}$

En Mulata de tal, el suspenso aparece en varias ocasiones. Señalemos dos de ellas: (1) el largo diálogo entre Felícito y Celestino (cap. 6 y 7) durante el cual éste piensa con angustia creciente que aquél disimula su naturaleza demoníaca; (2) las diferentes peripecias del duelo entre Celestino y Jerónimo, así como entre Celestino y Chimalpín, detalladamente descritas (cap. 22 a 24) de manera a permitirle al lector que disfrute de las sutiles estrategias de engaño y de disimulo de los contrincantes.

\subsubsection{El repaso}

El repaso recuerda acontecimientos leídos en episodios anteriores para facilitar la comprensión de la historia. En general, al confiar en la memoria del lector experto a quien pretende dirigirse, la novela culta evita este tipo de redundancia que estorba la fluidez de la narración. No es así en la novela popular, supuestamente dirigida a lectores inexpertos. En Mulata de tal aparece un repaso importante en el capítulo 22 cuando Celestino (poseído por Candanga) refiere al sacristán Jerónimo (poseído por la propia Mulata) muchas de sus aventuras anteriores. Otro repaso ocurre en el capítulo 30 en el momento en que la Tintorera le cuenta al mismo Jerónimo la historia de la Mulata de tal y de Celestino (Asturias, 2000a: 354-359).

\subsubsection{La ramificación}

Otro de los dispositivos de la novela popular consiste en renovar la intriga ramificándola gracias a la frecuente introducción de personajes y motivos nuevos. Por ejemplo, en las aventuras de Rocambole, héroe emblemático de la novela por entregas del siglo XIX inventado por Ponson du Terrail, se acude a dicho recurso de manera tan paroxística que alcanza una incoherencia insalvable (Thoveron, 1996: 168). En Mulata de tal, el reemplazo en Tierrapaulita del viejo sacerdote y de su sacristán por Chimalpín y Jerónimo, así como la aparición de la Huasanga, que transforma la rivalidad binaria entre Catalina y la Mulata en rivalidad ternaria, cumplen con esa función de expansión. Además de la inserción de nuevos actantes, la

\footnotetext{
${ }^{26}$ El "santo fuego", es decir la viruela, fue llevada a América por los españoles. Esos "tiempos más felices" pueden remitir por lo tanto a épocas anteriores a la Conquista.

27 Traducimos nosotros.
} 
metamorfosis de los antiguos favorece también la ramificación diegética. ${ }^{28} \mathrm{Si}$ las transformaciones sucesivas de Celestino expresan por ejemplo el paso del leñatero por diferentes etapas de su periplo iniciático, también permiten desencadenar nuevas intrigas como la del robo de gallinas (cap. 11) o la del baile de los gigantones (cap. 16).

\subsection{Conclusión II}

Desde el punto de vista de la representación ideológica de las identidades, Carpentier y Asturias divergen totalmente. Mientras el escritor cubano reconstituye el espejismo de una Arcadia colonial, el guatemalteco otorga al encuentro de civilizaciones una fisonomía grotesca. Todo ello se lleva a cabo con el rescate, tanto por Carpentier como por Asturias, de formas literarias populares y tradicionales, adecuadas a la intención americanista de los realismos maravillosos. Sin embargo, hemos observado que en las modalidades y en los resultados formales y estéticos de ese rescate, los escritores vuelven a diferir. Asturias adopta en efecto un tono carnavalesco mediante el cual la tradición popular pierde su carácter unitario y épico y se disuelve en un surtido de disyunciones alucinadas dentro de formas variadas, algunas provenientes de la hibridación contemporánea, otras de la literatura decimonónica por entregas. Carpentier en cambio recurre a una conmemoración solemne con el fin de ensalzar -ambiguamente, por medio de una sofisticada novela moderna- los valores épicos y firmes de una tradición homogénea, buscada con ahínco, pero sin éxito, por el mismo narrador.

\section{Referencias bibliográficas}

Asturias, Miguel Ángel (2000a [1963]). Mulata de tal. Ed. de Arturo Arias. Madrid/Barcelona/La Habana: ALLCA XX-colección Archivos. (2000b [1965]), “Algunos apuntes sobre Mulata de tal", en Miguel Ángel Asturias. Mulata de tal. Madrid/Barcelona/La Habana: ALLCA XX-colección Archivos, pp. 1005-1011.

Bajtín, Mijail (1971). La cultura popular en la Edad Media y el Renacimiento. El contexto de François Rabelais. Trad. de Julio Forcat y César Conroy. Barcelona: Barral editores.

Barrenechea, Ana María (1996 [1979]), "La literatura fantástica: función de los códigos socioculturales en la constitución de un tipo de discurso", en Lectura crítica de literatura americana. Inventario, invenciones y revisiones. Tomo I. Ed. de Saúl Sosnowski. Caracas: Biblioteca Ayacucho, págs. 30-39.

Barrientos Tecún, Dante (2000), "Structure éclatée, metamorfosis del personaje y parodia en Mulata de tal (1963)", en Miguel Ángel Asturias. Mulata de tal. Madrid/Barcelona/La Habana: ALLCA XX-colección Archivos, págs. 872890 .

Butor, Michel (1960 [1949]), “Le point suprême et l'âge d'or à travers quelques œuvres de Jules Verne”, en Essais sur les modernes. Paris: Gallimard, págs. 35-94.

Caillois, Roger (1966 [1958]), "De la féerie à la science-fiction”, en Anthologie du fantastique, tome I. Paris: Éditions Gallimard, págs. 7-24.

Carpentier, Alejo (1967 [1949]), "Prólogo", en El reino de este mundo. Santiago: Editorial Universitaria, págs. 9-16.

----- (2003 [1953]). Los pasos perdidos. Madrid: Alianza Editorial.

--------, ----- (1981). La novela latinoamericana en vísperas de un nuevo siglo y otros ensayos. México: Siglo XXI editores.

Collard, Patrick (1989), "La máscara, el traje y lo teatral en Los pasos perdidos de Alejo Carpentier", en Actas del IX Congreso de la Asociación Internacional de Hispanistas. Ed. de Sebastian Neumeister. Frankfurt am Main: Vervuert Verlag, págs. 507-514.

------, ----- (1991). Cómo leer a Alejo Carpentier. Madrid: Ediciones Júcar.

Durán Luzio, Juan (1978) Creación y utopía: letras de Hispanoamérica. San José de Costa Rica: Editorial de la Universidad Nacional.

Eco, Umberto (1993 [1978]). De Superman au surhomme. Trad. de Myriem Bouzaher. Paris: Grasset.

García Méndez, Javier (2002). Lectura de Los pasos perdidos de Alejo Carpentier. Paris: Ellipses éditions.

Goodman, Nelson (2010). Manières de faire des mondes. Trad. de Marie-Monique Popelard. Paris: Gallimard.

Juan-Navarro, Santiago (2002), "Las cárceles imaginarias de Sísifo: visión de la urbe arquetípica en Los pasos perdidos", en La représentation de l'espace dans le roman hispano-américain. Ed. de Néstor Ponce. Nantes: Éditions du temps, págs. 167-177.

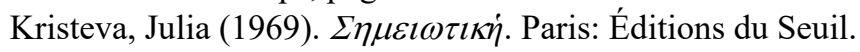

----- (1968), "Le texte clos", Langages, vol. 3, nº. 12, págs. 103-125. 
Lara Figueroa, Celso (1990). Cuentos y consejas populares de Guatemala. Guatemala: Ediciones Artemis.

Llarena, Alicia (1997a). Realismo mágico y lo real maravilloso: una cuestión de verosimilitud (espacio y actitud en cuatro novelas latinoamericanas. Gaithersburg: Ediciones Hispamérica.

(1997b), "Un balance crítico: la polémica del realismo mágico y lo real maravilloso americano (19551993)", Anales de literatura hispanoamericana, vol. 26, núo 1, págs. 107-117.

Martín Rodríguez, Mariano (2013), "Mundos perdidos, paraísos perdidos: ciudad primitiva y utopía imposible en Los que no descienden de Eva (1941), de Luis Antonio de Vega", Ángulo Recto. Revista de estudios sobre la ciudad como espacio plural, vol. 5, $\mathrm{n}^{\mathrm{o}}$. 1, págs. 45-64. Disponible en : http://www.ucm.es/info/angulo/volumen/Volumen05-1/articulos03.htm.

Pavel, Thomas (1988). Univers de fiction. Paris: Éditions du Seuil-collection Poétique.

Popol Vuh. Las antiguas historias del Quiché (1952). Trad., introd. y notas de Adrián Recinos. México: Fondo de Cultura Económica.

Propp, Vladimir (1970). Morphologie du conte. Trad. de Marguerite Derrida, Tzvetan Todorov y Claude Kahn. Paris: Éditions du Seuil.

Tadié, Jean-Yves (1982). Le roman d'aventures. Paris: Presses Universitaires de France-Quadrige.

Thoveron, Gabriel (1996). Deux siècles de para-littératures. Lecture, sociologie, histoire. Liège: Éditions du CÉFAL.

Velayos Zurdo, Oscar (1990). Historia y utopía en Alejo Carpentier. Salamanca: Ediciones Universidad de Salamanca. 